\title{
Towards a new time scale for the Upper Miocene continental series of the Pannonian basin (Central Paratethys)
}

\author{
M. Sacchi ${ }^{1}$ and F. Horváth ${ }^{2}$ \\ ${ }^{1}$ Istituto per l'Ambiente Marino Costiero (IAMC), Consiglio Nazionale delle Ricerche (CNR), Calata Porta di Massa, Porto \\ di Napoli, 80100 - Napoli, Italy \\ ${ }^{2}$ Eötvös University, Department of Geophysics, Pázmány Péter sétány 1/C - 1117 - Budapest, Hungary
}

Received: 2 May 2000 - Accepted: 29 May 2002

\begin{abstract}
In this study we assert that most of the "Pontian" stratigraphic succession of western Hungary is much older than Pontian stage (older than $7 \mathrm{Ma}$ ). In fact, these strata form a clearly distinct chronostratigraphic unit between the Pontian strata (as they are defined in the type area of the Black Sea basin) and the Pannonian strata (as they are defined in the type area of the Vienna basin). To denote such a problematic chronostratigraphic interval we propose the introduction of a new stage (or substage) named Transdanubian between the Pannonian sensu stricto (s.s.) and Pontian s.s. stages of the Upper Miocene series of the Central Paratethys System (ca. 9.0-7.4 Ma in the chronology adopted in this study).

The Transdanubian stage has been defined in terms of biostratigraphy, lithostratigraphy, magnetostratigraphy and allostratigraphy. The location of a suitable stratotype has also been proposed. As a first approach, we tried to avoid the introduction of new terms in the already complex chronostratigraphic nomenclature of the Pannonian basin. However, we arrived to the conclusion that the introduction of the Transdanubian as a new stage (or substage) is a necessary breakthrough, to avoid further confusion and circular reasoning involving facies associations versus chronostratigraphic units.

Transdanubian strata represent a distinct anticipation of the Pontian facies within the intra-Carpathian area. The fact that these strata have been reported for decades as "Pontian" in the literature has been the source of much terminological confusion and chronostratigraphic miscorrelation.
\end{abstract}

\section{Introduction}

During the Oligocene-Neogene the Pannonian basin was part of a vast epi-continental basin system that developed as a series of brackish seaways, lakes and wetlands within the interiors of central Eastern Europe and western Asia. Ma-

Correspondence to: $\mathrm{M}$. Sacchi

(sacchi@gms01.geomare.na.cnr.it) jor relics of this ancient aquatic realm, called Paratethys (Laskarev, 1924), are represented by the present-day Black Sea, the Caspian Sea and the Aral Sea (Fig. 1). It is generally accepted that open to restricted marine conditions prevailed in the Pannonian basin throughout the syn-rift phase (Lower Miocene to early Mid Miocene). However, since the early post-rift phase (late Mid Miocene) the basin became an isolated brackish-water lake that was progressively filled up by large prograding delta systems.

Establishing a reliable chronostratigraphic framework for the Neogene non-marine sedimentary fill of the Pannonian basin and understanding the variation in space and time of facies associations at basin scale have been long-debated problems. Paratethys stages were based mainly on mollusk assemblages. Correlation among marine episodes in the Paratethys was obtained by marine planktonic microfossils, while correlation of regional stages of the Paratethys with the standard marine stages still remains somewhat obscure, being practically impossible in terms of biostratigraphy only (Magyar and Hably, 1994; Sacchi et al., 1997, 1999a, b). Nowadays consensus seems to be emerging around the need of a multidisciplinary approach to integrate the classic biostratigraphic analysis and geologic mapping on a lithostratigraphic base (Sacchi, 2001).

According to the regional chronostratigraphy adopted for the nonmarine strata of the intra-Carpathian area (Central Paratethys) the Upper Miocene-Pliocene sequence of the Pannonian basin (Pannonian stage sensu (s.) Lôrenthey, 1900, or "Pannonian sensu lato" (s.l.), is subdivided into Pannonian sensu Stevanović, 1951, or "Pannonian sensu stricto" (s.s.) and Pontian (s. Andrussov, 1887) stages. An informal twofold subdivision into "Lower Pannonian" and "Upper Pannonian" is also used in Hungary, particularly in the practice of seismic-stratigraphic interpretation. In this case the term "Lower Pannonian" is often assumed to correspond to the Pannonian stage s.s. and the term "Upper Pannonian" to the Pontian stage, respectively. It is beyond the scope of this paper to review the historical development of the Pannonian s.l. non-marine stratigraphy of the Central Paratethys. 


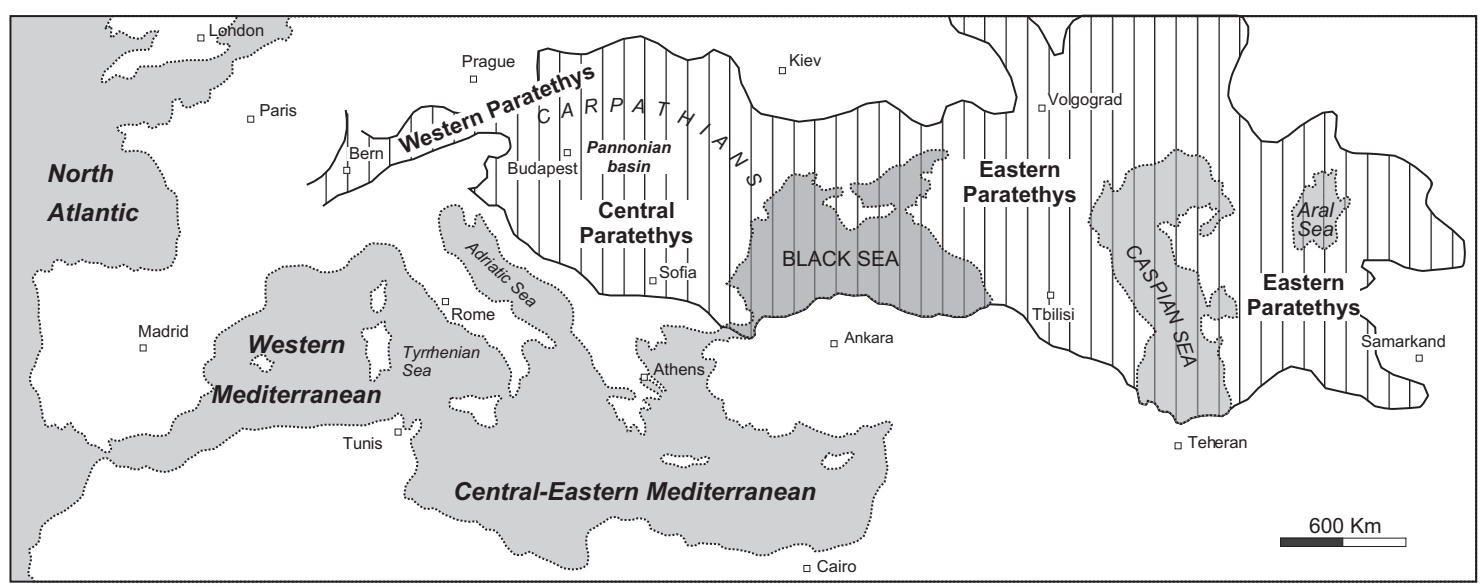

Fig. 1. Outline of the Paratethys-Mediterranean region during Late Miocene (after Müller et al., 1999).



Fig. 2. Historical development of the Pannonian stage of the Central Paratethys and correlation with the standard Neogene time scale. Note that a three-fold subdivision of Pannonian s.l. strata (s. Lőrenthey, 1900) similar to the one discussed in this study had been already introduced, early last century, by Hörnes (1901) and Halaváts (1903).

The reader is referred to the detailed reviews of KorpásHódi (1983), Papp et al. (1985), Steininger et al. (1990), Stevanović et al. (1990), Rögl (1996, 1998), Sacchi et al. (1997, 1999b), Magyar et al. (1999a, b), Müller et al. (1999), Sacchi (2001) (Fig. 2).

In the last few years several authors have pointed out that the Late Miocene chronostratigraphy of the Paratethys is affected by terminological and conceptual inconsistencies
(Müller and Magyar, 1992; Magyar and Hably, 1994; Gyalog, 1996; Sacchi et al., 1997, 1999a, b; Horváth and Tari, 1999). Particularly it has become clear that none of the stage names currently used in the literature adequately represent the middle part of the Pannonian s. Lôrenthey (1900) (ca. 9.0-7.4 Ma, in the chronology adopted in this study). The reason for the inadequacy of the official Paratethys stage system in offering a reliable chronostratigraphic picture of the 


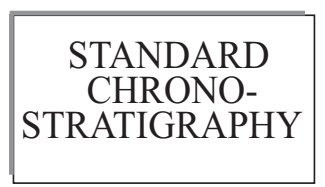

a)

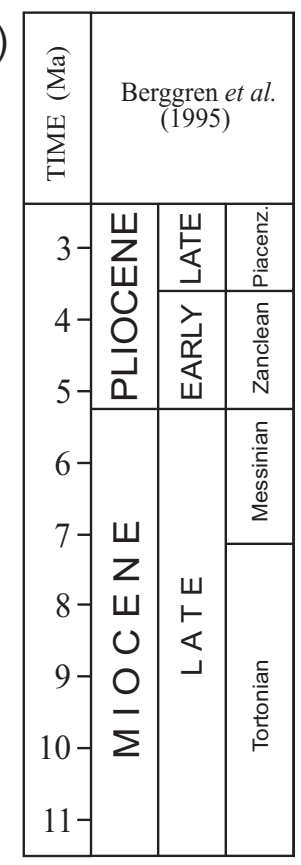

b)

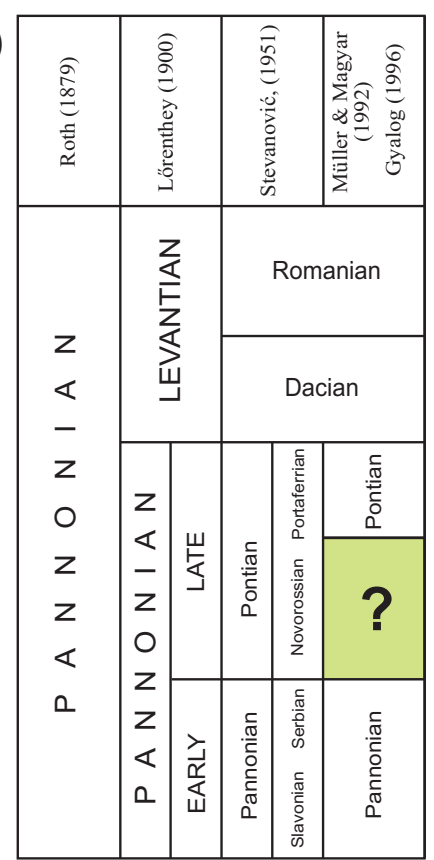

c)

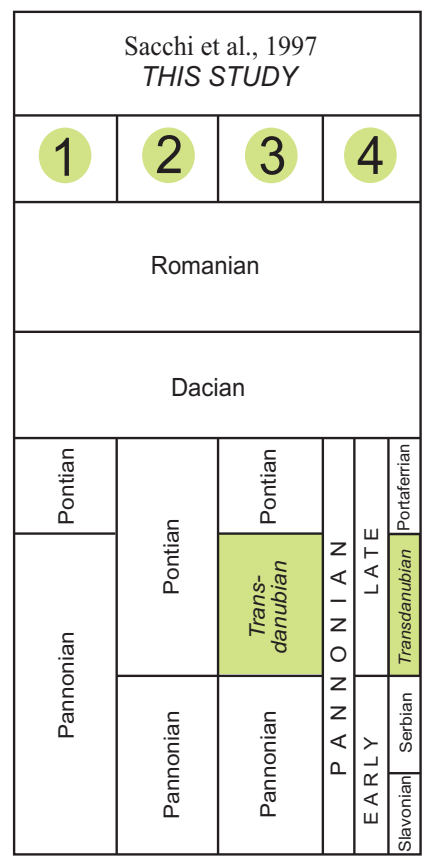

1 Shift the boundary between Pannonian s. str. and Pontian s. Stevanović (1951) up to the base of the Pontian as it is defined in its type section of the Eastern Paratethys.

2 Maintain the Pontian s. Stevanović (1951) only for the Central Paratethys and use the term Pontian with two different meanings.

3 Introduce a new stage (Transdanubian) in order to fill the "chronostratigraphic gap" between the Pannonian s. str. and Pontian s. str. .

4 Delete the stage name "Pontian" from the Western-Central Paratethys stage system and reintroduce the use of the term "Pannonian" s. Lörenthey (1900).

Fig. 3. Correlation between the Late Neogene (a) Mediterranean and (b) Central Paratethys stages. Column (c) illustrates four possible redrawings of the Late Miocene chrono-stratigraphic framework of the Pannonian basin (Central Paratethys) (from Sacchi et al., 1997, slightly modified) (see text for discussion).

Pannonian s.l. stage is multifold. Among the important factors hindering time-stratigraphic correlation there are:

1) the general diachronous trends of the lithostratigraphic patterns in the Paratethys continental realm (younging from West to East);

2) documented radiations and migrations of endemic mollusk faunas from central to eastern Paratethys during Late Miocene-Pliocene;

3) the remarkable facies dependence of faunas which makes it difficult to recognize the First and Last Occurrence of index fossils (Sacchi, 2001).
In this study we propose a new chronostratigraphic framework of the Upper Miocene continental record of the Pannonian basin, in the stratigraphic interval corresponding to the Tortonian-lowermost Messinian of the standard marine time scale (ca. 9.0-7.0 Ma in the chronology adopted in this study). The opportunity to introduce the concept of Regional Stratotype Sections and Points (RSSPs) for large (intra)continental bioprovinces as regional standards for marine-continental correlations is also discussed. 


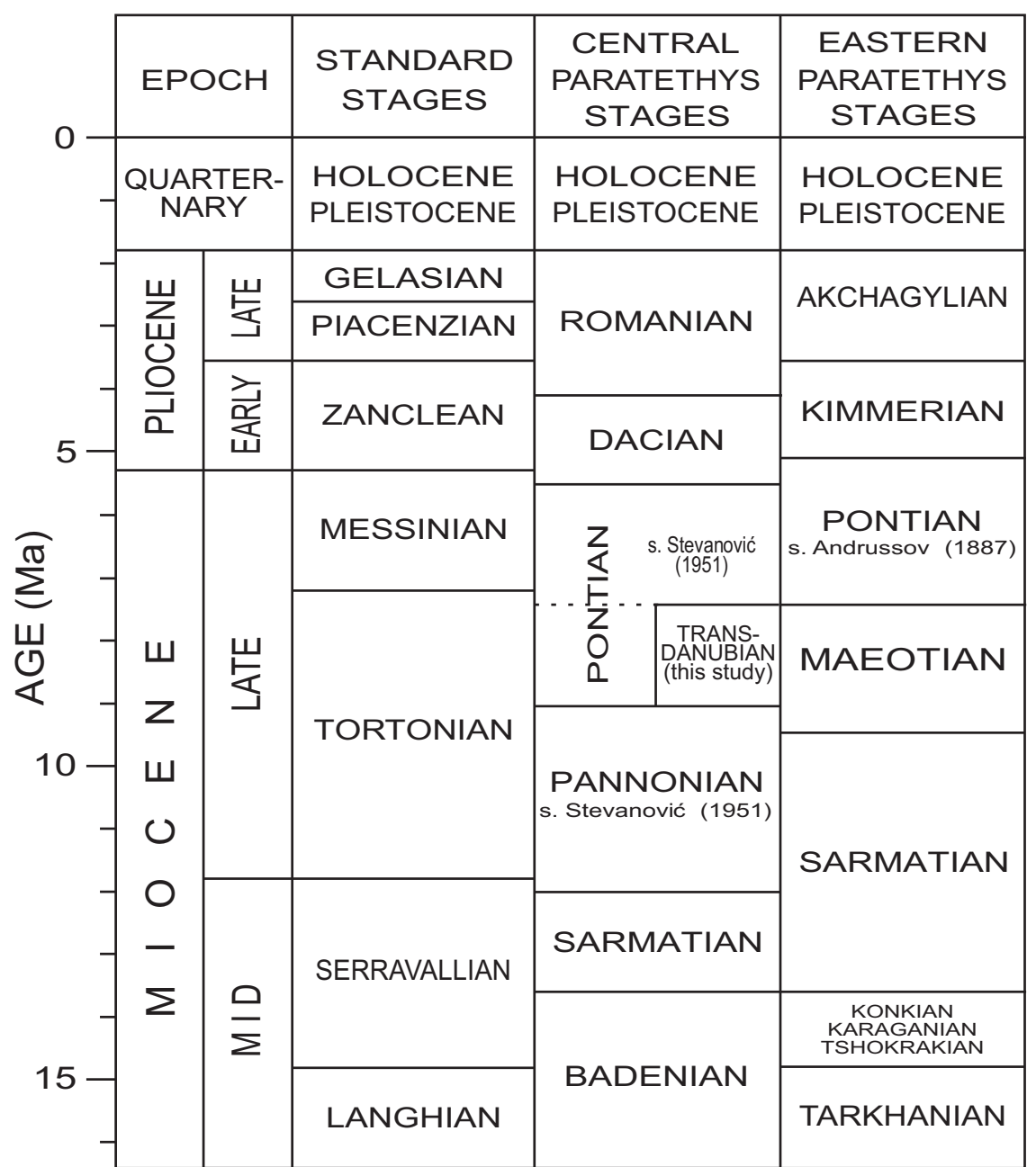

Fig. 4. Mediterranean and Paratethys stages for the last $15 \mathrm{Ma}$ (after Rögl, 1998 and Magyar et al. (1999a, b). In this study we adopt the Transdanubian (Sacchi, et al., 1999a, b) as an intermediate stage (or substage) between the Pannonian s.str. (s. Stevanović, 1951) and the Pontian s.str. (Andrussov, 1887). The Transdanubian substitutes the lower part of Pontian s. Stevanović (1951).

\section{The need for a new time scale}

Chronostratigraphic miscorrelation between the base of the eastern Paratethys Pontian (Pontian s.str.) and the base of the Central Paratethys Pontian (Pontian s. Stevanović, 1951) due to diachronism of biofacies was first demonstrated in the Pannonian basin by Müller and Magyar (1992). This problem was largely a consequence of the correlation suggested by Stevanović (1951) who proposed the "extension" of the Pontian stage of the eastern Paratethys to the central Paratethys realm, based on the presumed coeval appearance of common mollusc species on both sides of the Carpathians. However, the Pontian mollusc fauna of the Eastern Paratethys practically consists of Pannonian Lake (Central Paratethys) immigrants and their descendants, and hence is much younger than its intra-Carpathian counterpart (Müller et al., 1999).

The fact that the base of the Pontian s.str. stage is nearly 2 Ma younger than the top of the Pannonian s.str actually represents a major obstacle in the chronostratigraphic procedure within the Central Paratethys. This circumstance recalls the attention on the practice of adopting a stage defined in the Eastern Paratethys (like the Pontian s.str.) for chronostratigraphic subdivision in the Central Paratethys. The problem is very complex indeed, as the term "Pontian" has deep roots in the literature. It is widely used in the Mediterranean region by both Paratethyan and Mediterranean stratigraphers, and certainly, it would not be easy to convince workers to substitute it with a new stage name "labeled" for Central Paratethys use only. On the other hand, the correlation of the Eastern Paratethys Pontian with time-equivalent strata of the Central Paratethys is still obscure.

One might consider that an easy (conceptual, not practical) solution to the problem would be to "stretch" the upper boundary of the Pannonian s.str. stage (s. Stevanović, 1951) up to the lower boundary of the Pontian s.str. stage (e.g. Rögl, 1996, 1998). This solution, unfortunately, would cause even more confusion in the terminology. In fact, the "short" Pannonian s.str. stage (Stevanović, 1951) at least had the basic advantage of being correlative with the Lower Pannonian of the Hungarian literature (s. Lőrenthey, 1900; Halaváts, 1903). This equivalence appears to be deeply rooted and stable in the Central Paratethys stratigraphic terminology of the last decades. With the eventual upward shifting of the top of the Pannonian s.str. stage this correlation would be lost, and much confusion would arise. Furthermore, the uppermost strata of a "stretched" Pannonian stage would include 
sedimentary deposits that display typical "Pontian facies" resemblance and have been referred to as Pontian for decades.

Whatever the solution may be, the key question remains how to fill the "chronostratigraphic gap" between the Pannonian s.str. and Pontian s.str. stages (Fig. 3). In the following pages possible options to "fill" this "gap" within the Upper Miocene series of the Pannonian basin are presented and discussed. Particularly we adopt the Transdanubian (ca. 9.0-7.4 Ma in the chronology discussed in this study) as an intermediate stage (or substage) between the Pannonian s.str. (s. Stevanović, 1951) and the Pontian s.str. (Andrussov, 1887) (Fig. 4).

\section{The regional stratigraphic framework of SW Pannon- ian Basin}

Several studies have been recently published on the sequence stratigraphy of the Upper Neogene fill of the Pannonian basin (Pogácsás et al., 1988; Elston et al., 1990; Csató, 1993; Ujszászi and Vakarcs, 1993; Vakarcs et al., 1994, Vakarcs, 1997). The results we present in this paper are based on the recent recognition and correlation of unconformity-bounded stratigraphic units within the non-marine Upper Miocene strata of the western Pannonian basin (Sacchi et al, 1999a). Based on methods and procedures of sequence stratigraphy (Vail, 1987; Galloway, 1989), five 3rd-order (with $10^{6}$ year periodicities) sequences at regional scale in the Upper Miocene succession of the western Pannonian basin have been recognized (Fig. 5). The sequence stratigraphic procedure was applied not as a rigid model or template, but rather to promote an integrated stratigraphic approach. This includes full combination of biostratigraphy, magnetostratigraphy, radiometric age determination, sequence (or genetic) stratigraphy and classic field study (Sacchi et al., 1999a).

A detailed lithostratigraphic and paleontologic description along with geophysical logs of Iharosberény-I well were used in this study. Available magnetostratigraphic data included magnetic polarity logs from a number of wells in the Hungarian part of the Pannonian basin (Lantos et al., 1992, Juhász, 1994; Lantos and Elston, 1995; Magyar et al, 1999b; Sacchi et al., 1999a). Iharosberény-I well log has been correlated with the global magnetic polarity scale (Kande and Kent, 1995, Berggren et al., 1995) and seismic reflectors in the Southern Transdanubia. The obtained sequence stratigraphic framework was tied to a regional biostratigraphic and magnetostratigraphic framework recently developed for the Upper Miocene succession of the Pannonian basin (Juhász et al., 1999; Magyar et al., 1999a, b; Müller et al., 1999). Radiometric data on volcanic rocks interbedded within the Upper Miocene continental strata of western Hungary were also used to constrain chronostratigraphic interpretation (Balogh et al., 1986; Balogh, 1995; Pécskay et al., 1995).

\subsection{Magnetostratigraphy}

Iharosberény- 1 is one among a series of continuously cored exploratory wells drilled in the Hungarian part of the Pannonian Basin that have been processed for detailed magnetostratigraphic study (Juház et al., 1994, 1999; Magyar et al., 1999). The sedimentary succession cored at Iharosberény-1 displays no evidence for movement of connate or ground water and the strata seem to have remained undisturbed and unexposed since burial. Therefore, the study samples most likely display original magnetization (Magyar et al., 1999b); minor secondary magnetization disappeared at 10-30 mT (Elston et al., 1990, 1994; Lantos and Elston, 1995). Details of paleomagnetic studies have been published elsewhere (Elston et al., 1990, 1994; Kokay et al., 1991; Lantos et al., 1992; Lantos and Elston, 1995.

The magnetic polarity zones of Iharosberény-1 well section have been correlated to the Global Polarity Time Scale (GPTS) of Cande and Kent, 1995 (Fig. 6). The magnetic polarity zones detected within the Iharosberény-1 core section lie above the long normal polarity interval of Chron C5n (Juház et al., 1999; Magyar et al., 1999a). The first two normal polarity intervals in the lower part of the section between ca. $1100 \mathrm{~m}$ and $1075 \mathrm{~m}$ and $990 \mathrm{~m}$ and 900 may be namely correlated with chrons C4Ar.1n and C4An. Similarly, the major uppermost four normal polarity intervals at $180-240 \mathrm{~m}, 275-310 \mathrm{~m}, 380-410 \mathrm{~m}, 425-500 \mathrm{~m}$ can be namely correlated to Chrons C3Bn, C3Br.2n, C3Br.1n and $\mathrm{C} 4 \mathrm{n} .2 \mathrm{n}$. Less obvious is the calibration of the large and discontinuous normal polarity zone developing at depth of $525 \mathrm{~m}$ to $850 \mathrm{~m}$. Juház et al. (1999) and Magyar et al. (1999) have proposed that the base of Chron C4n.1n can be located at a depth of ca. $730 \mathrm{~m}$. in the Iharosberény-1 section.

\subsection{Sequence stratigraphy}

The Upper Miocene stratigraphic sequences of the SW Pannonian basin have been designated from bottom to top, as Sarmatian-1 (SAR-1) and Pannonian-1 (PAN-1) through Pannonian-4 (PAN-4). The stacking pattern of stratigraphic sequences gives a general picture of the evolutionary stages of the prograding delta systems in the SW Pannonian basin. Maximum thickness of the whole sequence stack is in the order of $3 \mathrm{~km}$. The major unconformity at the base of the post-rift sequence of the western Pannonian basin in Southern Transdanubia is often associated with a significant stratigraphic gap whose amplitude increases from WSW (Drava basin) to ENE (Somogy). This may cause amalgamation of more sequence boundaries (Fig. 5).

Calibration of seismic profiles with borehole data shows that maximum flooding surface mfs- 2 marks the peak of a major flooding event associated with large scale transgression of Congeria czjzeki lacustrine beds (Szák Fm.) onto the Pannonian basin margins. Mfs- 2 correlates with the base of magnetic polarity zone C4An and hence can be dated at 9.03 Ma. It represents a quasi-isochronous surface at basin 

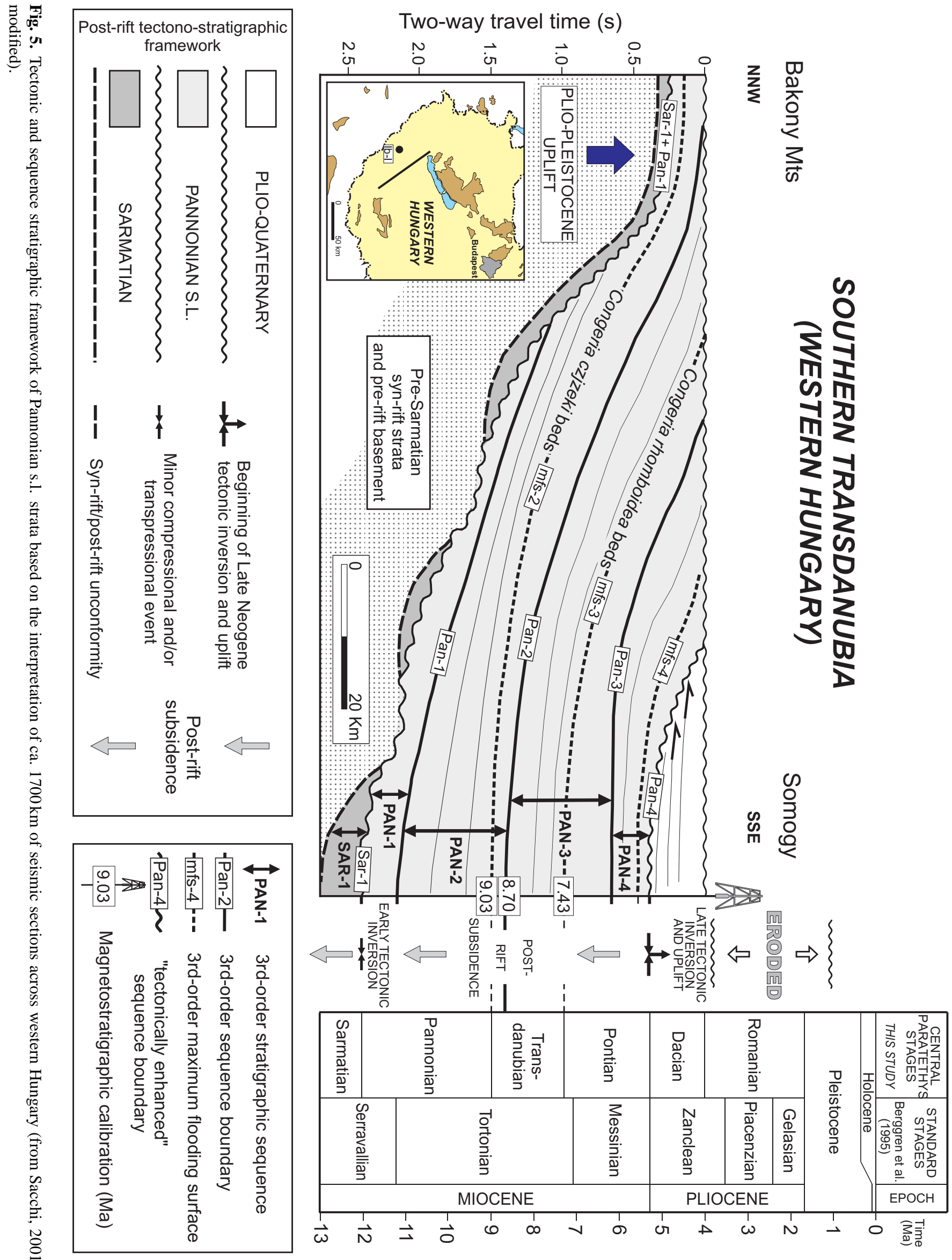


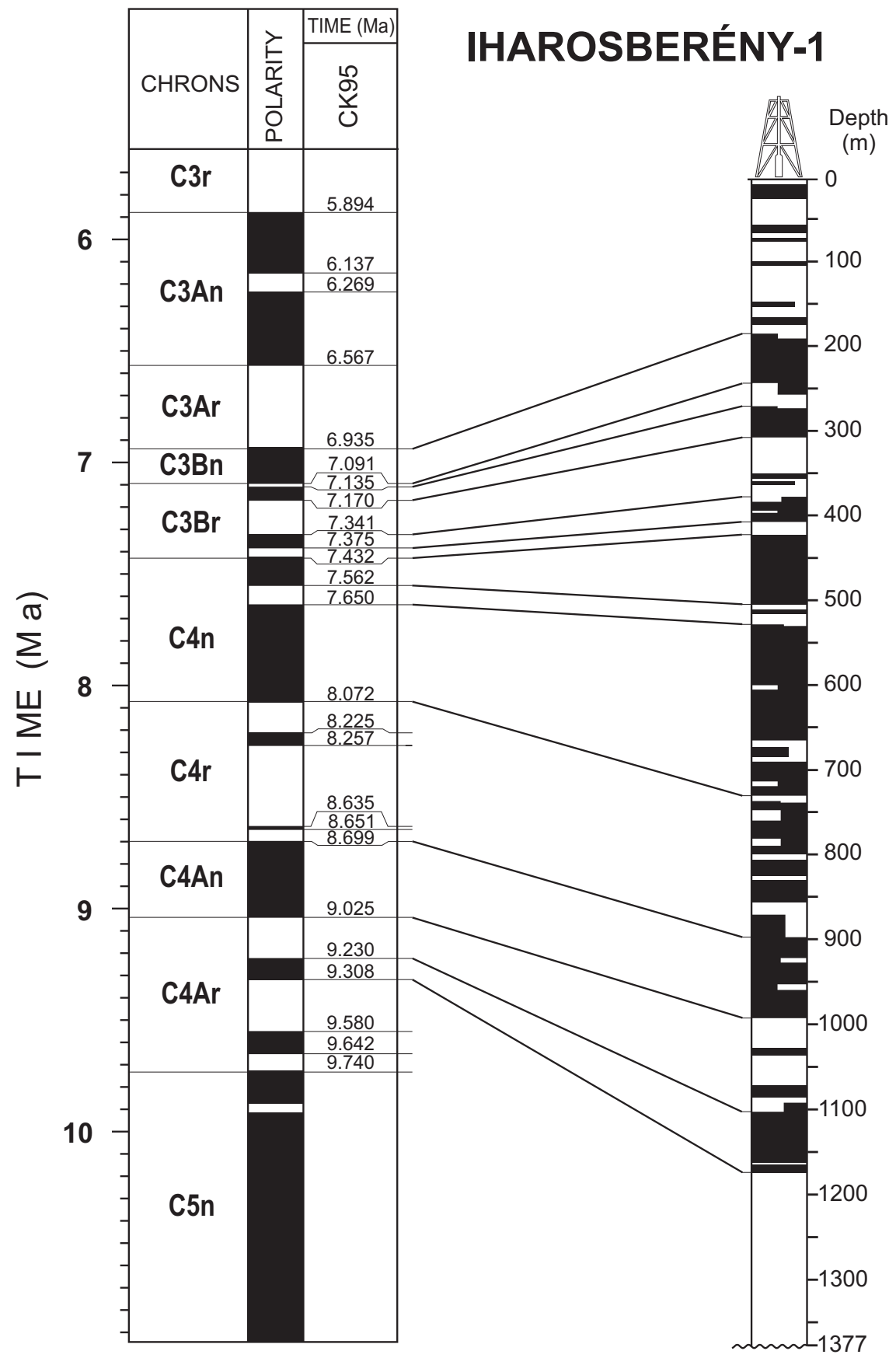

Fig. 6. Correlation of Iharosberény-1 well polarity zones with the Global Polarity Time Scales (GPTS) of Cande and Kent (1995) (CK95) (after Juhász et al., 1994, 1999; Magyar et al., 1999b; Sacchi, 2001).

scale and correlates with the top of Pannonian s.str. stage (Lower Pannonian s. Lörenthey, 1900) (Figs. 5-8).

Sequence boundary Pan-2 correlates with the base of zone C4r (ca. 8.7 Ma). It is associated with a significant drop of base level of erosion within the Pannonian basin, which was accompanied by extensive subaerial exposure of the lake margins. This is documented in the so-called marginal facies of Transdanubia (Sacchi, 2001).

Maximum flooding mfs-3 is within the lower part of zone $\mathrm{C} 3 \mathrm{Br}$ (ca. 7.4 Ma). It represents the final stage of a second important flooding event within the basin, which is again characterized by the development of open lake strata. Subsurface data show maximum flooding surface mfs-3 may be correlated to offshore lacustrine marl with Congeria rhomboidea. This surface represents another useful quasi timeline at basin scale that may be regarded as a good proxy in western Hungary for the base of Pontian as it is defined in the stratotype area of the Black Sea basin. Consequently, the stratigraphic unit bounded by maximum flooding surfaces mfs- 2 and mfs- 3 can be correlated with the lower part Pontian s. Stevanović (1951). This unit can be seen as an "anticipation" of the Pontian s.str. facies in Hungary. According to 

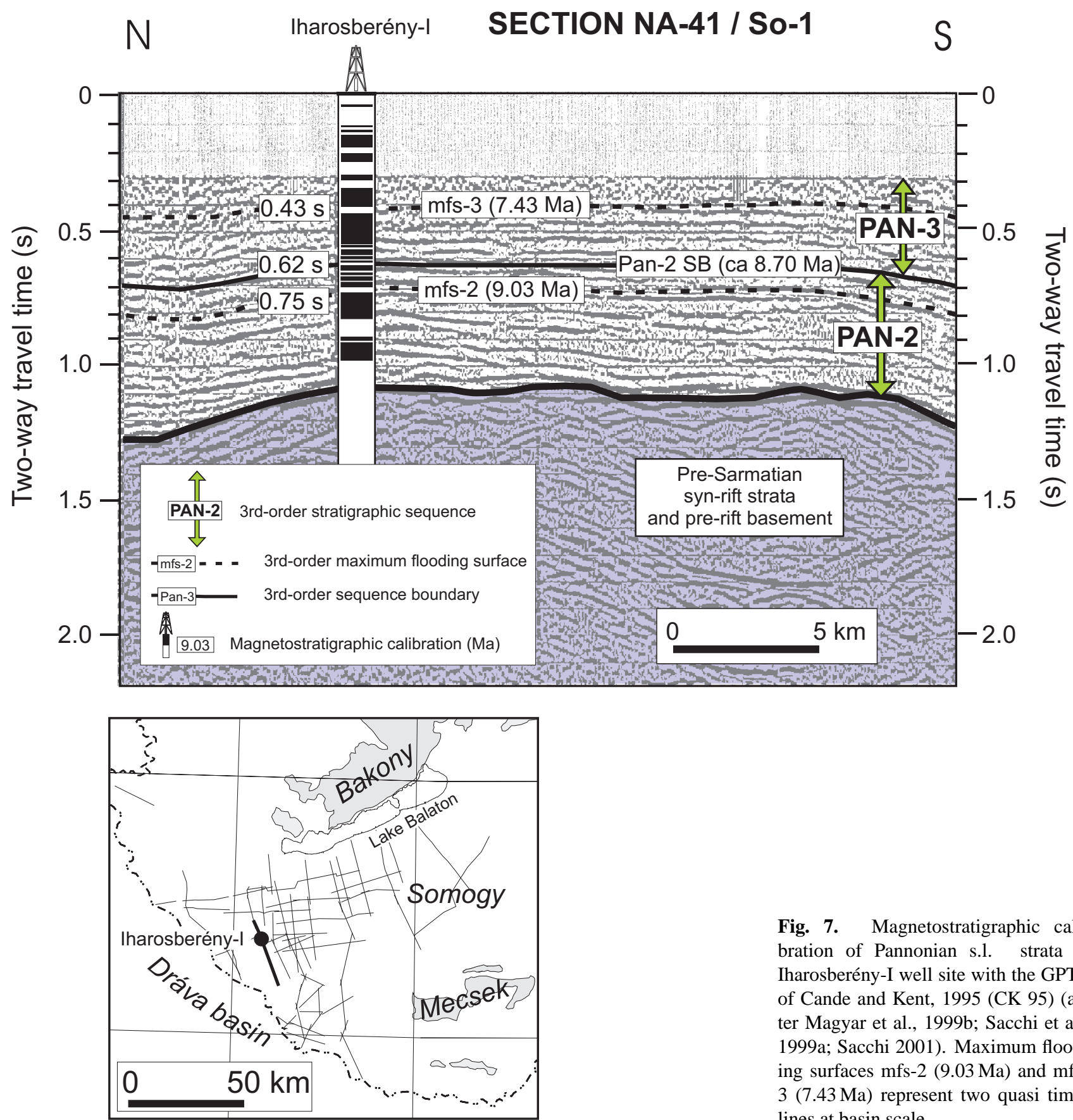

Fig. 7. Magnetostratigraphic calibration of Pannonian s.l. strata at Iharosberény-I well site with the GPTS of Cande and Kent, 1995 (CK 95) (after Magyar et al., 1999b; Sacchi et al. 1999a; Sacchi 2001). Maximum flooding surfaces mfs-2 (9.03 Ma) and mfs3 (7.43 Ma) represent two quasi timelines at basin scale.

this interpretation it is concluded that Pontian s.str. (younger than $7 \mathrm{Ma}$ ) strata are practically missing in outcrop in centralwestern Hungary.

Sequence boundary Pan-4 (ca. 5.0 Ma) is likely to be associated with a stratigraphic gap (Juhász et al., 1999) and significant tectonic overprint as suggested by the general tectono-stratigraphic patterns within the Neogene basin fill. The higher rank unit bounded by Pan-1 SB and Pan-4 SB approximately correlates with the Tortonian-Messinian strata of the standard time scale. The major unconformity developing at Pan-4 SB subdivides the post-rift strata of western Pannon- ian basin into two main tectono-stratigraphic units namely Late Miocene and Pliocene in age (Fig. 5).

\section{Definition of Transdanubian stage (or substage)}

Based on the integrated stratigraphy of the Upper Miocene succession of SW Pannonian basin discussed in this study, we propose the introduction of the Transdanubian stage in the regional chronostratigraphic scale of the Central Paratethys (Fig. 9). The Transdanubian is intended to substitute the 


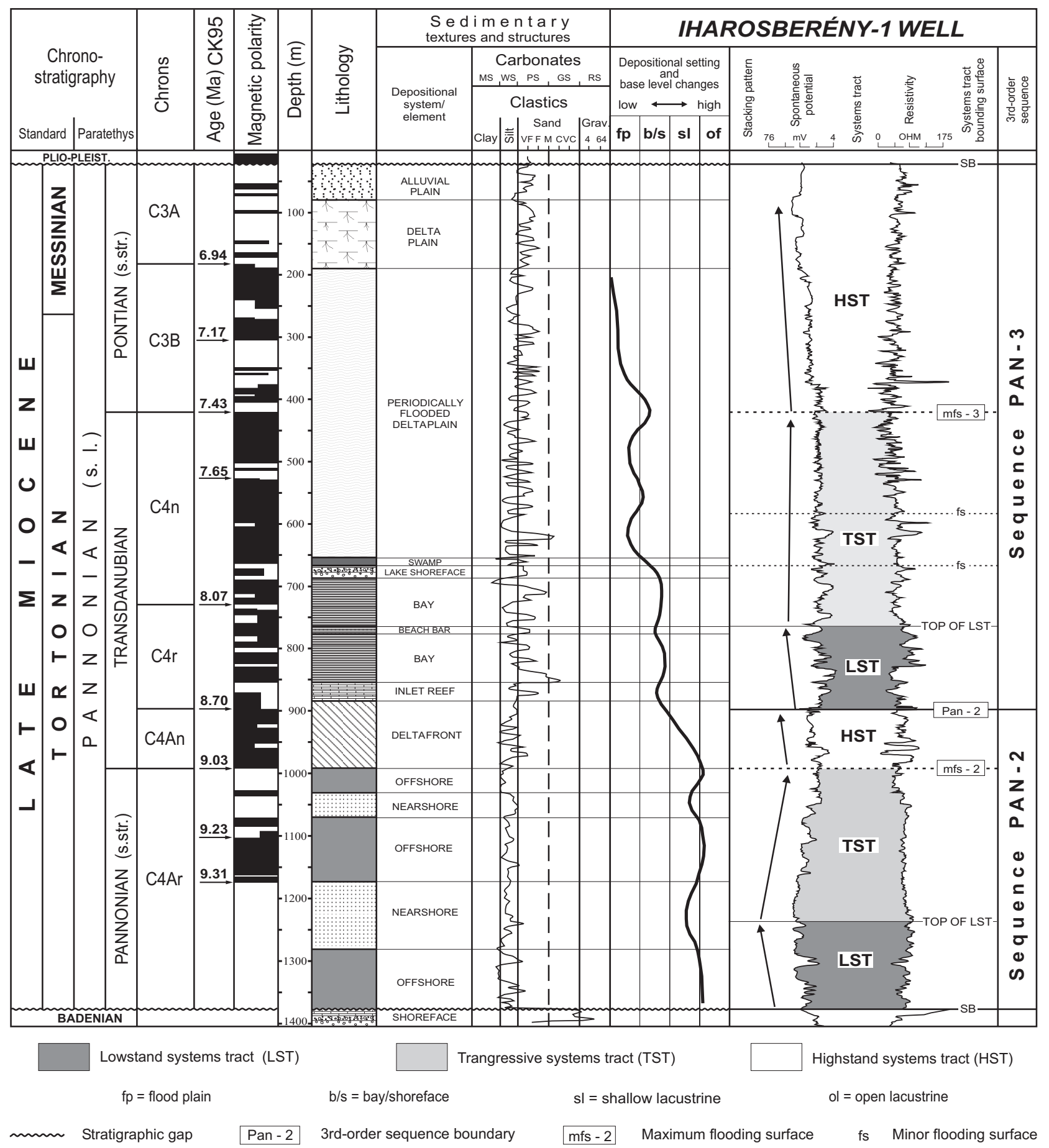

Fig. 8. Interpretation of the Pannonian s.l. (Upper Miocene) succession cored at Iharosberény-1 well site, western Pannonian basin, Hungary. Chronostratigraphic subdivision of Pannonian s.l. strata is after Sacchi et al. (1999a, b). Magnetic polarity zones have been calibrated to the GPTS of Cande and Kent (1995) (CK95).

lower part of the "Pontian" s. Stevanović (1951) which revealed to be significantly older than Pontian age s.str.

In terms of the informal chronostratigraphy often used in Hungary, the Transdanubian may be introduced as the third middle subdivision of the Pannonian s.l. stage (s. Lôrenthey, 1900). It is worth noting that the concept of an intermedi- ate stage between "Lower Pannonian" (Pannonian s.str.) and "Upper Pannonian" (Pontian s.str.) is not new. In fact since the earliest stratigraphic studies on Pannonian strata, Hörnes (1901) had defined a "Middle Pontian" interval (Mittlere Congerienschichten) and Halaváts (1903) "Middle Pannonian" strata (Congeria ungulacaprae and Congeria balatonica 


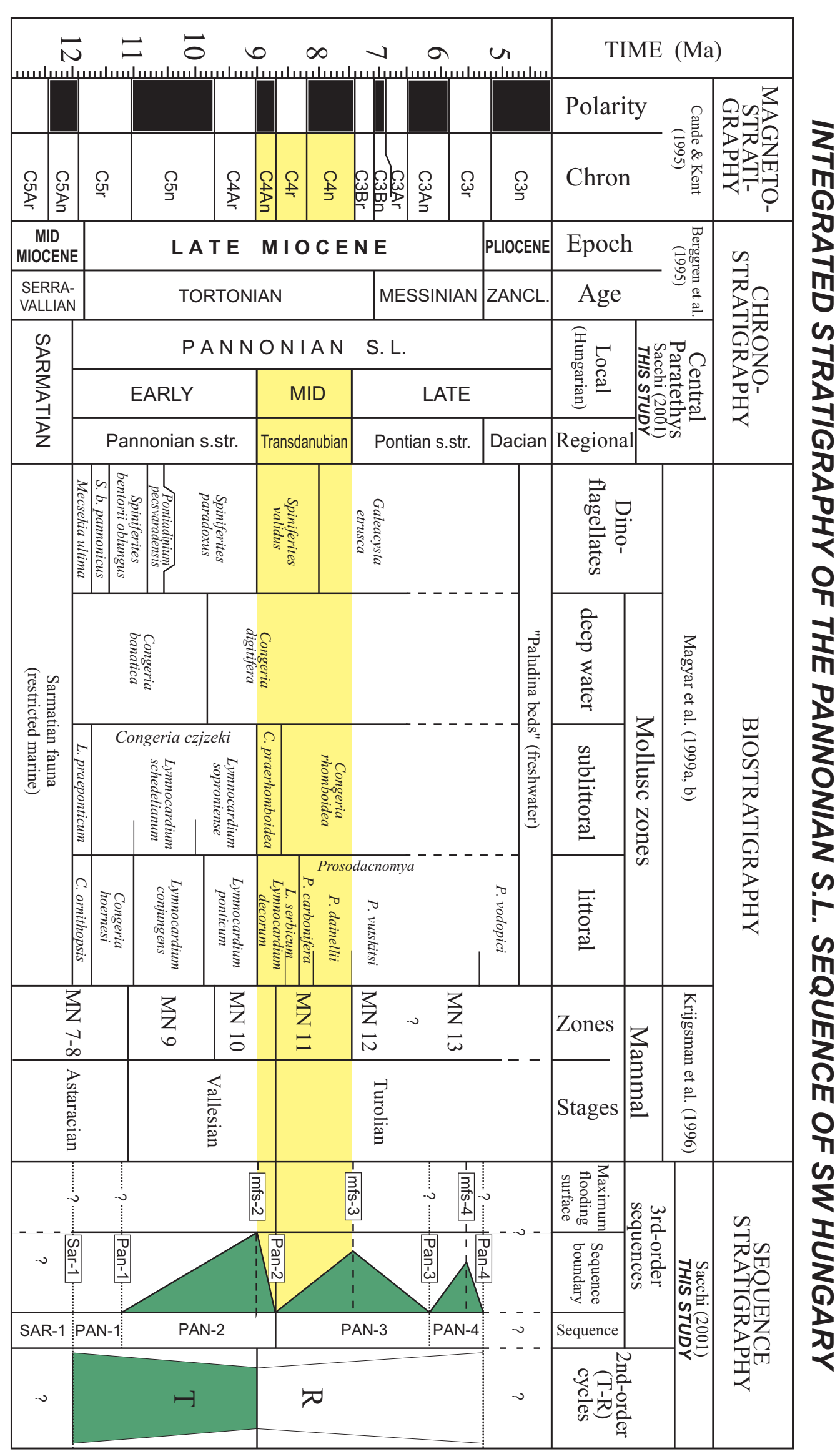



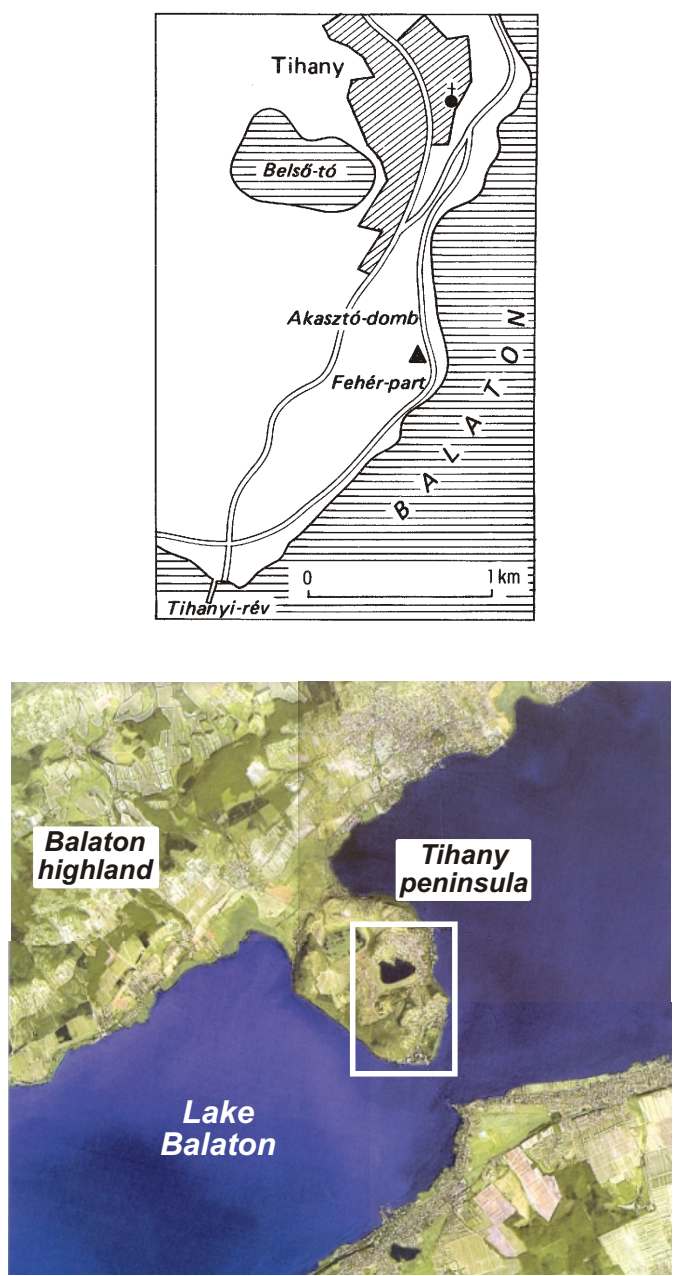

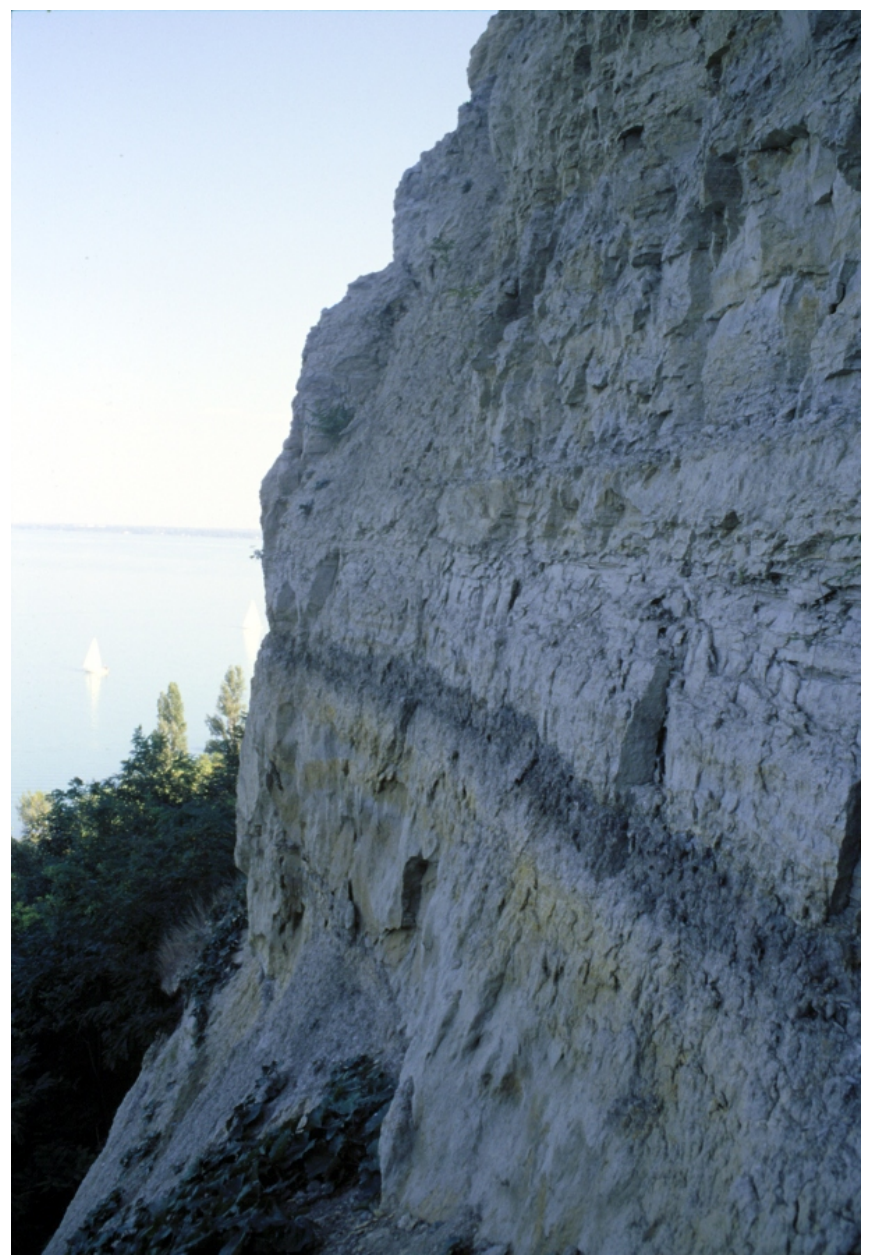

Fig. 10. Alternating shallow lacustrine and terrestrial strata cropping out at Tihany- Fehérpart, Lake Balaton. The section is currently regarded as Pontian faciostratotype in Hungary (Müller and Szónoky, 1990). Our study showed, however, that these strata are much older than the Pontian stage. We suggest this section may be selected as Transdanubian stratotype (ca. 9.0 to 7.4 Ma).

beds). Both these stratigraphic units substantially coincide with the Transdanubian stage defined and discussed in this study.

The Transdanubian time interval is actually not represented in any proposed stratotype of the Miocene Series of the Central Paratethys.

Name - The name "Transdanubian" is proposed after the name of the inner Carpathian region west of the Danube river, to denote the stratigraphic interval in study. It is the region of Hungary where the best outcrops of these rocks can be found.

Rank of the Chronostratigraphic Unit - The Transdanubian has a duration of ca. 1.6 Ma. It could be ascribed to the rank of stage or substage, depending on the reorganization of the general chronostratigraphic framework.

Location of the stratotype - A suitable stratotype for the Transdanubian stage is represented by the Tihany-Fehérpárt section which is presently used as faciostratotype for local (Hungarian) reference to the Pontian facies of the Black Sea (Müller and Szonóky, 1990). This section is exposed at the northern shore of Lake Balaton, western Hungary (Fig. 10).

Selection of a boundary stratotype - The lower boundary of Transdanubian stratotype section is not exposed at Tihany-Fehérpárt, but has been cored in the near subsurface $(55.4 \mathrm{~m}$ beneath the topographic surface at Lake Balaton shore, Tihany-62 well). This stratigraphic level crops out in the northern Transdanubia (Bakony, Vértes, Gerecse Mts.) and more research work should be to be done to select an appropriate Transdanubian boundary stratotype in this area. A possible candidate in scope may be preliminarily selected in the clay pit sections exposed at Tatabánya area at the boundary between the open lacustrine strata (Szák Fm.) and the base of the overlying silty layers of Somló Fm (top of the Congeria czjzeki bearing beds).

Biostratigraphic definition - In terms of molluscan biozonation (Magyar et al, 1999b) the Transdanubian stage corresponds to the littoral Congeria balatonica-Lymnocardium (decorum-serbicum) zone and the Congeria ungulacapraeProsodacnomya (carbonifera-dainelli) zone (see Middle Pannonian of Halaváts, 1903). Its lower part correlates 


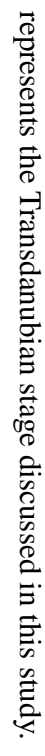

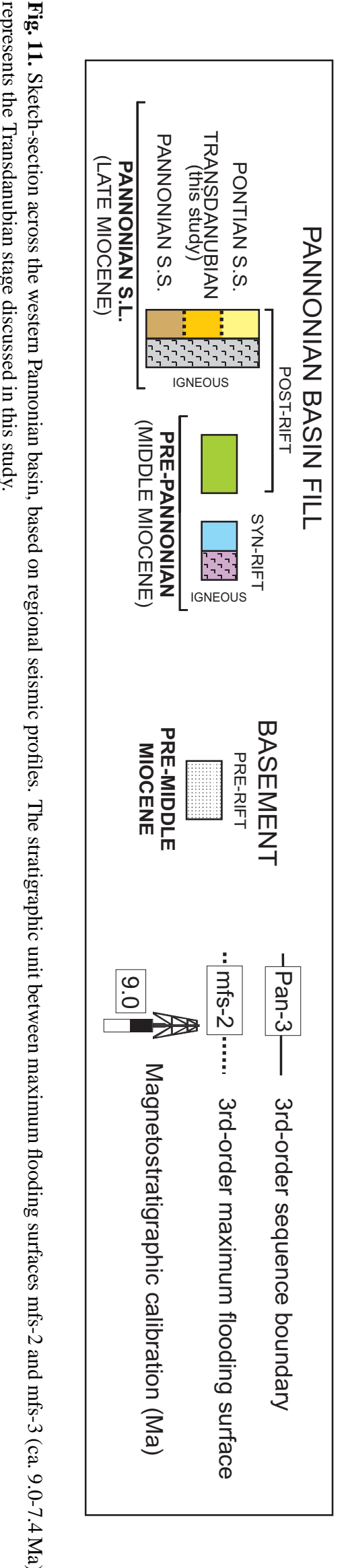

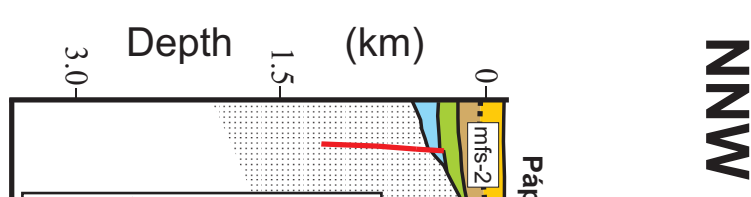

$\sum_{\Sigma}$

d
$\frac{1}{2}$
$z$

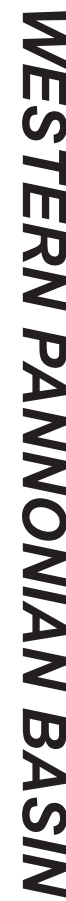

3
ก
ก
$\frac{m}{x}$

$\mathscr{\mathscr { C }}$ 

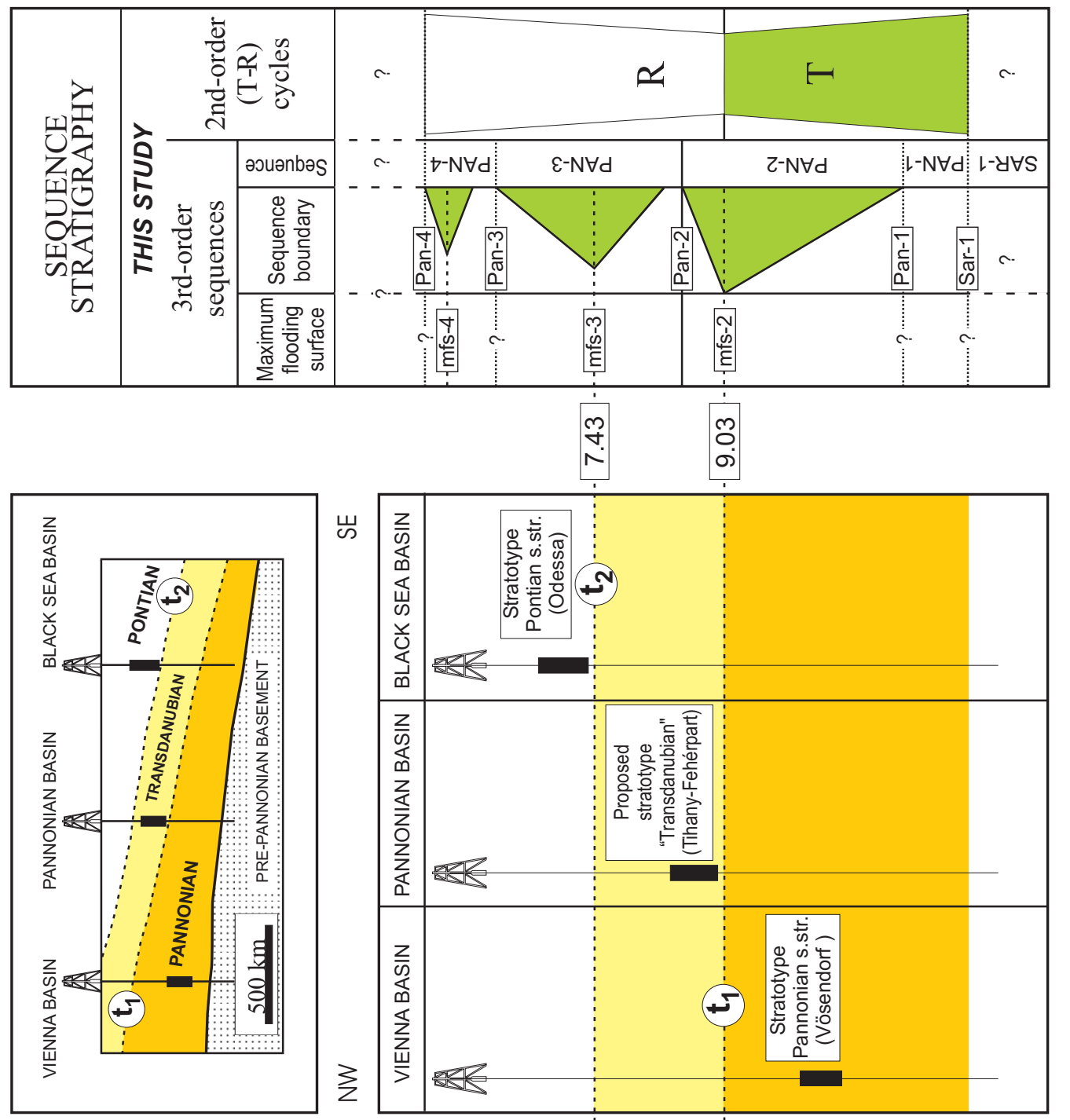

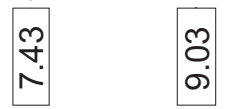

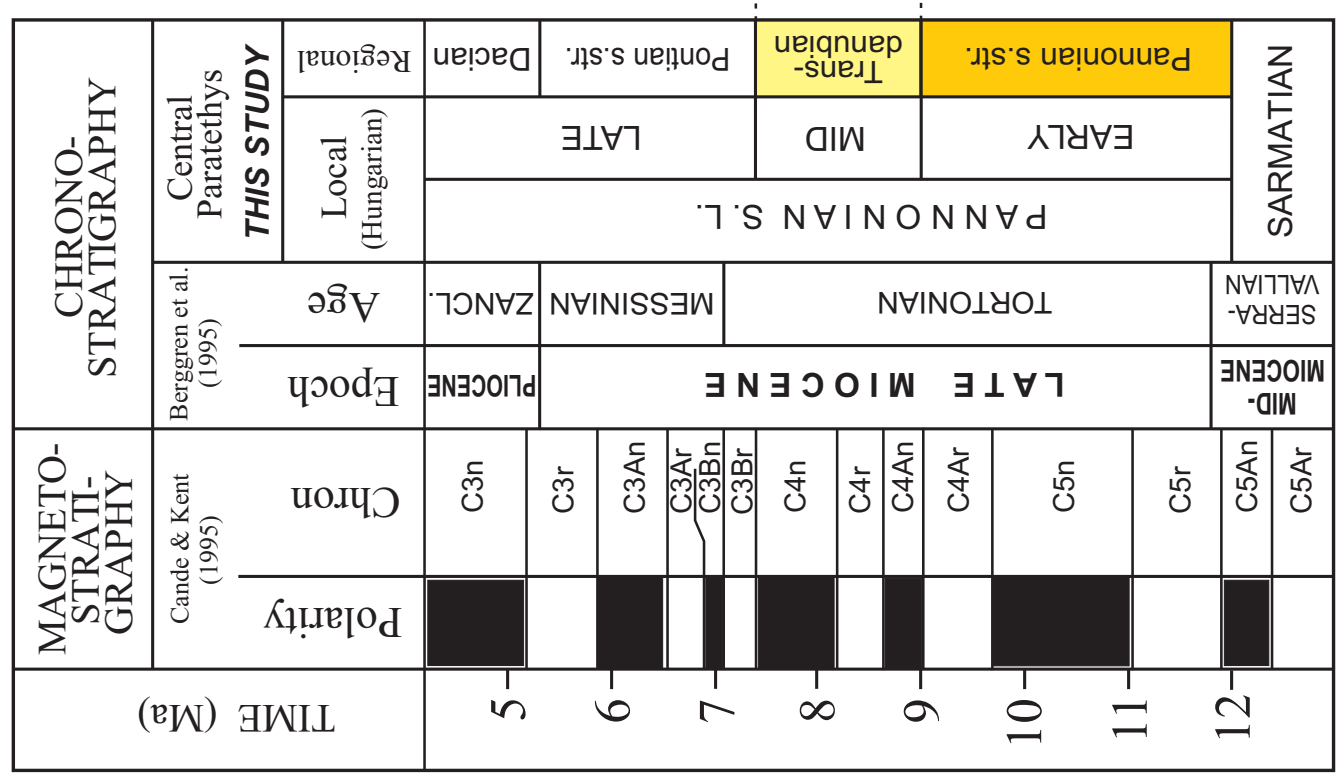


to the sublittoral Congeria praerhomboidea zone and the Spiniferites validus microplankton zone, though it may outreach their rather uncertain upper boundaries. The lower boundary of the Transdanubian correlates with the base of Chron C4An and displays an age of $9.03 \mathrm{Ma}$, while the upper boundary is within the lower part of zone $\mathrm{C} 3 \mathrm{Br}$ ( $7.43 \mathrm{Ma}$ ) (Fig. 9).

Allostratigraphic definition - From the perspective of allostratigraphy (Salvador, 1994) the Transdanubian stage may be defined as a genetic stratigraphic unit (s. Galloway, 1989) bounded by two consecutive third-order maximum flooding surfaces, namely, mfs- 2 and mfs- 3 of this study (Fig. 11). Transdanubian strata correspond to a regressivetransgressive cycle that can be regarded as an "anticipation" of the Pontian facies of the Black Sea in Hungary.

Recognition of Transdanubian boundaries in the outcrop and subsurface - As they correspond to maximum flooding surfaces, both boundaries of the Transdanubian stage are easily recognized in the outcrop (sharp facies contrast between the underlying open lacustrine beds and the overlying regressive fluviatile-terrestrial strata) as well as in deep seismics (high-amplitude and high-lateral continuity of reflectors at the top of transgressive systems tract typically overlain by downlapping strata of the highstand systems tract deposits).

Completeness of the boundary stratotype section - Regional stratigraphic correlation indicates that the critical interval for defining the base of the Transdanubian stage is remarkably complete in the whole northern Transdanubian area. Sequence stratigraphy predicts that condensation and/or minor non-depositional hiatus may occur at maximum flooding surfaces. However if hiatuses occur, their duration is likely to be below the resolution provided by biostratigraphy.

Magnetostratigraphic definition - Based on correlation with calibrated magnetostratigraphy of Iharosberény-I well, the lower boundary of the Transdanubian stage can be placed at the base of chron C4An of the global magnetic polarity scale (Cande and Kent, 1992, 1995; Berggren, 1995) (Figs. 7-9).

Geochronology - According to the revised calibration of global magnetic polarity scale of Cande and Kent (1995), the lower boundary of the Transdanubian stage displays a magnetostratigraphic age of 9.025 Ma (Figs. 7-9).

Potential correlation with Eastern Paratethys stages Based on its integrated stratigraphic definition the Transdanubian stage as a first approach, might be tentatively correlated with the Maeotian stage of the Eastern Paratethys (Pevzner, 1987).

\section{Discussion}

If the Late Miocene chronostratigraphy of the Mediterranean can be regarded as one of the best known time intervals of the stratigraphic column, on the other end the Late Miocene chronostratigraphy of Central-Eastern Europe (Central Paratethys) appears to be, some decades after its in- troduction, still far from satisfactory. Apart from the obvious difficulties in correlating non-marine stages of the Paratethys and standard marine stages, the Paratethys Stage System is clearly affected by severe internal inconsistency. Particularly, the boundaries and the internal subdivision of the broad time interval between the Sarmatian (Mid-Late Serravallian) and the Pleistocene have not been unambiguously defined at interregional scale.

In the last decades, the use of different names or even different meanings for the same names has proliferated to such an extent that, possibly, the only unequivocal chronostratigraphic term one could use to indicate rocks of that time interval is "Pannonian" (s. 1.) as it was originally introduced by Roth (1879) more than a century ago.

One "mission" of stratigraphy is trying to find the largest international consensus around the definition and convenience in the practical use of Stages. In fact, modern trends in chronostratigraphy include the concept of Global Stratotype Section and Points (GSSPs). Of course one cannot approach the chronostratigraphic study of the Paratethys bioprovince (although it is a huge bioprovince) in terms of "global" stages. Nevertheless, we believe it might be worthwhile to agree upon regionally valid, useful, and accepted definition of stages. The wider the region where a certain stage can be successfully tested and used, the higher is its intrinsic value. Therefore, an international cooperation and effort would be required in order to work out "Regional (i.e. Paratethyan) Stratotype Section and Points" (RSSPs) (Fig. 12). This would probably be a necessary step towards the process of abandoning excessive fragmentation and proliferation of local chronostratigraphic subdivisions within the continental realm of Paratethys.

\section{Conclusions}

We propose the introduction of the Transdanubian as an intermediate stage (or substage) between the Pannonian s.str. and Pontian s.str stages of the Upper Miocene series of the Central Paratethys System (ca. 9.0-7.4 Ma in the chronology adopted in this study) (Figs. 2, 4 and 9).

The reason for introducing a new stage in the already complex chronostratigraphic framework of the Paratethys stage system is twofold. The Transdanubian stage is a rock unit likely to be recognizable at regional scale and it may significantly enhance stratigraphic correlation in the Central Paratethys. On the other hand, we consider its introduction as a necessary breakthrough, to avoid further confusion and circular reasoning involving facies associations versus chronostratigraphic units.

Transdanubian strata correspond to a regressive-transgressive cycle that can be regarded as an "anticipation" of the Pontian facies of the Black Sea in Hungary (Fig. 12). The introduction of the Transdanubian stage may help to unravel the long-lasted debate on Late Neogene chronostratigraphy of the central Paratethys. A major impact of the new stratigraphic correlation we present in this study is the significant 
revision of Late Miocene paleogeographic reconstruction of the Mediterranean area and timing of geodynamic processes in the Pannonian basin.

Acknowledgements. This research has benefited from joint work and fruitful discussion at various stages with Imre Magyar and Pál Müller who are kindly acknowledged here. We thank JeanPierre Berger, Davide Castradori, Maria Bianca Cita, András Nagymarosy, András Galácz, Fred Rögl, Fritz Steininger, Günter Schweigert and Dionz Vass, for their suggestions and comments. Sincere thanks are also due to two anonymous referees who significantly improved the early version of manuscript and to Patricia Sclafani who revised the English text.

This work was supported by the Italian-Hungarian Cooperation Agreement (CNR-MTA) for the period 1998-2000.

\section{References}

Andrussov, N.: Geogische Untersuchungen in der westlichen Hälfte der Halbinsel Kertsch, Bull. D. Société d. natur. D. 1. Nouv. Russie, 2, 69-147, 1887.

Balogh, K.: K/Ar study of the Tihany Volcano, Balaton Highland, Hungary, Report on the work supported by the European Community in the frame of program "IBS", Institute of Nuclear Research, Hungarian Academy of Sciences, Debrecen, pp12, 1995.

Balogh, K., Árva-Sós, E., Pécskay, Z., and Ravasz-Baranyai, L.: $\mathrm{K} /$ Ar dating of Post-Sarmatian alkali basaltic rocks in Hungary, Acta Miner. Petrogr., 28, 75-93, 1986.

Berggren, W. A., Hilgen, F. J., Langereis, C. G., Kent, D. V., Obradovich, J. D., Raffi, I., Raymo, M. E., and Shackleton, N. J.: Late Neogene chronology: New perspectives in high-resolution stratigraphy, GSA Bullettin, 107, 11, 1272-1287, 1995.

Cande, S. C. and Kent, D. V.: Revised calibration of the geomagnetic polarity time scale for the Late Cretaceous and Cenozoic, Jour. of Geoph. Res., 100, B4, 6093-6095, 1995.

Csató, I.: Neogene sequences in the Pannonian Basin, Hungary, Tectonophysics, 226, 377-400. 1993.

Eltson, D. P., Lantos, M., and Hámor, T.:, Magnetostratigraphic and seismic stratigraphic correlations of Pannonian (s. 1.) deposits in the Great Hungarian Plain. Annu. Rep. Hung. Geol. Surv., 1988 (I), 110-134, 1990.

Eltson, D. P., Lantos, M., and Hámor, T.: High-resolution polarity records and the stratigraphic and magnetostratigraphic correlation of the Late Miocene and Pliocene (Pannonian s. 1.) deposits of Hungary, in: Teleki, P. G., Mattick, R. E., Kókai, J. (Eds.): Basin Analysis in Petroleum Exploration. A case study from the Békés basin, Hungary, Kluwer Academic Publishers, Dordrecht, 111-142, 1994.

Fejfar, O.: Tableau stratigraphique de l'Eocene superieure au Pleistocene, Symp. de Günzburg (unpublished), 1988.

Galloway, W. E.: Genetic stratigraphic sequences in basin analysis I: architecture and genesis of flooding surface-bounded depositional units, AAPG Bullettin, 73, 125-142, 1989.

Gyalog, L. (Ed.): A földtani térképek jelkulcsa és a rétegtani egységek rövid lerása (Key of geological maps and short description of the lithostratigraphical units) - MÁFI alk. kiadv. (Hung. Geol. Surv.), Budapest, 1-171, 1996.

Halaváts, J.: Die Fauna der pontischen Schichten der Umgebung des Balatonsees, in: Resultate der wissenschaftlichen Erforschung des Balatonsees, 1/1, Palaontologischer Anhang 4/2, Holzel, Wien, 1-80, 1903.
Horváth, F. and Tari, G.: IBS Pannonian Basin project: a review of the main results and their bearings on hydrocarbon exploration, in: Durand, B. Jolivet, L., Horváth, F., and Séranne, M. (Eds.): The Mediterranean Basins: Tertiary Extension within the Alpine Orogen, Geological Society, London, Special Publications, 156, 195-213, 1999.

Hörnes, R.,: Congeria Oppenheimi und Hilberi, zwei neue Formen der Rhomboidea-Gruppe aus den oberen pontischen Schichten von Königsgnad (Királykegye), Sitzungsberichte d. kais. Akad. d. Wiss., math.-naturw. Klasse, Bd. CX. Abth. I., 206-236, 1901.

Jámbor Á.: Review of the geology of the s.l. Pannonian formations of Hungary, Acta Geol. Hung., 32 (3-4), 269-324, 1989.

Juhász, E., Kovács, L. Ó., Müller, P., Tóth-Makk, Á., Phillips, L., Lantos, M.: Climatically driven sedimentary cycles in the Late Miocene sediments of the Pannonian basin, Hungary, Tectonophysics, 282, 257-276, 1997.

Juhász, E., Budai, T., Farkas-Bulla, J., Hámor, T., Lantos, M., Müller, P., Tóth-Makk, Á.: A Pannon-medence Neogén üledékeinek vészletes sedimentológiai fácies-elemzése és értékelése. Jelentés az IBS project kekretében végzett munkákról, ELTE Geofiz. Tsz., könzvtár, Budapest, 1994.

Juhász, E., Phillips, L., Müller, P., Ricketts, B., Tóth-Makk, Á., Lantos, M., Kovács, L. Ó.: Late Neogene sedimentary facies and sequences in the Pannonian Basin, Hungary, in: Durand, B. Jolivet, L., Horváth, F., and Séranne, M. (Eds.): The Mediterranean Basins: Tertiary Extension within the Alpine Orogen, Geological Society, London, Special Publications, 156, 335-356, 1999.

Kokay, J., Hamor, T., Lantos, M., and Müller, P.: The paleomagnetic and geological study of borehole section Berhida 3, Annual Report of the Hungarian Geological Institute, 1989, 45-63, 1991.

Korpás-Hódi, M. (Ed.): Dunántúli Középhegység - Paleoecology and biostratigraphy of the pannonian mollusca fauna in the northern foreland of the Transdanubian Central Range, Ann. Inst. Geol. Publ. Hung., 66, 163pp, 1983.

Krijgsman, W., Garcés, M., Langereis, C. G., Daams, R., van der Meulen, A. J., Agustí, J., and Cabrera, L.: A new chronology for the middle to late Miocene continental record in Spain, Earth and Planetary Science Letters, 142, 367-380, 1996.

Lantos, M. and Elston, D. P.: Low to high-amplitude oscillations and secular variation in a $1.2 \mathrm{~km}$ Late Miocene inclination record, Physics of the Earth and Planetary Interiors, 90, 37-53, 1995.

Lantos, M., Hámor, T. and Pogácsás, G.: Magneto- and seismostratigraphic correlations of Pannonian s.l. (late Miocene and Pliocene) deposits in Hungary, Paleontologia i Evolució, 24-25, 35-46, 1992.

Laskarev, V.: Sur les equivalents du Sarmatien superieur en Serbie, Recueil de travaux offert a M. Jovan Cvijic, Beograd, 1924.

Lőrenthey, I.: Foraminifera der pannonischen Stufe Ungarns, Neues Jb. f. Min. Geol. und Paläont., 2, 99-107, 1900.

Magyar, I. and Hably, L.: Stratigraphic position of late Neogene paleobotanical sites in Hungary: Miocene or Pliocene? Acta Paleobot. Polonica, 34 (2), 195-203, 1994.

Magyar, I., Geary, D. H., and Müller, P.: Paleogeographic evolution of the Late Miocene Lake Pannon in Central Europe, Palaeogeogr. Palaeoclimatol. Paleoecol., 147, 151-167, 1999a.

Magyar, I., Geary, D. H., Sütő-Szentai, M., Lantos, M., and Müller, P.: Integrated biostratigraphic, magnetostratigraphic and chronostratigraphic correlations of the Late Miocene Lake Pannon deposits, Acta Geol. Hung., 42/1, 5-31, 1999b. 
Mancini, E. A. and Tew, B. H.: Recognition of maximum flooding events in mixed siliciclastic-carbonate systems: Key to global chronostratigraphic correlation, Geology, 25, 351-354, 1997.

Müller, P. and Magyar, I.: Stratigraphic significance of the Upper Miocene lacustrine cardiid Prosodacnomya (Kötcse section, Pannonian basin, Hungary), Földtani Közlöny, Budapest, 112/1, 138, 1992.

Müller, P. and Szónoky, M.: Faciostratotype Tihany-Fehérpart (Hungary), ("Balatonica Beds" by Lőrenthey, 1905), in: Stevanović, P., Nevesskaya, L., Marinescu, F., Sokać, A., and Jámbor, Á. (Eds.): Chronostratigrapie und Neostratotypen, Neogen der westlichen ("Zentrale") Paratethys, Pontien, Jazu and Sanu, Zagreb-Beograd, 427-436, 1990.

Müller, P., Geary, D. H., and Magyar, I.: The endemic molluscs of the Late Miocene Lake Pannon: their origin, evolution and family-level taxonomy, Lethaia., 32, 47-60, 1999.

Papp, A., Jámbor, Á., and Steininger, F. F. (Eds.): Chronostratigraphie und Neostratotypen, Miozän der Zentralen Paratethys 7, Pannoniaen. Akadémiai Kiadó, Budapest, 636pp, 1985.

Pécskay, Z., Lexa, J., Szakács, A., Balogh, K., Seghedi, I., Konečny, V., Kovács, M., Márton, E., Kaliciak, M., Széky-Fux, V., Póka, T., Gyarmati, P., Edelstein, O., Rosu, E., and Zec, B.: Space and time distribution of Neogene-Quaternary volcanism rocks in the Carpatho-Pannonian Region, in: Downes, H. and Vaselli, O. (Eds.): Neogene and related magmatism in the CarpathoPannonian Region, Acta Vulcanol., 7, 15-28, 1995.

Pevzner, M. A.: The Pontian of the Eastern Paratethys: its duration and position in the magnetochronological scale, Ann. Inst. Geol. Publ. Hung., 70, 169-171, 1987.

Pogácsás, Gy., Lakatos, L., Újszászi, K., Vakarcs, G., Várkonyi, L., Várnai, P., and Révész, I.: Seismic facies, electro facies and Neogene sequence chronology of the Pannonian basin, Acta Geol. Hung., 31 (3-4), 175-207, 1988.

Roth, L.: Geologische Skizze des Kroisbach-Ruster Bergzuges und des südlichen Teiles des Leita-Gebirges, Földtani Közlöny, Budapest, 9, 139-150, 1879.

Rögl, F.: Stratigraphic correlation of the Paratethys Oligocene and Miocene. Mitt. Ges. Geol. Bergbaustud. Österr., Wien, 41, 6573, 1996.

Rögl, F.: Paleogeographic considerations for Mediterranean and Paratethys seaways (Oligocene and Miocene), Ann. Naturhist. Mus. Wien, 99 A, 279-310, 1998.

Rögl, F. and Steininger, F. F.: Vom Zerfall de Tethys zu Mediterran und Paratethys. Die neogene Paläogeographie und Palinspastik des zirkum-mediterranen Raumes, Ann. Naturhist. Mus. Wien, 85 A, 135-163, 1983.

Rögl, F., Bernor, R. L., Dermitzakis, M. D., Müller, C., and Stancheva, M.: On the Pontian correlation in the Aegean (Aegina Island), Newsletter Stratigr., 24 (3), 137-158, 1991.

Sacchi, M.: Late Miocene evolution of the western Pannonian basin, Hungary, Ph.D. thesis, Eötvös Loránd University, Budapest, Hungary, 193pp, 2001.

Sacchi, M., Horváth, F., and Magyari, O. : Role of unconformitybounded units in the stratigraphy of the continental record: a case study from the Late Miocene of the western Pannonian basin, Hungary, in: D. B. Jolivet, L., Horváth, F., and Séranne, M.: The Mediterranean Basins: Tertiary Extension within the Alpine Orogen, Geological Society, London, Special Publications, 156, 357-390, 1999a.

Sacchi, M., Horváth, F., Magyar, I., and Müller, P.: Problems and progress in establishing a Late Neogene Chronostratigraphy for the Central Paratethys, Neogene Newsletter, Padova, 4, 37-46, 1997.

Sacchi, M., Horváth, F., Magyar, I., and Müller, P.: Problems and progress in establishing a Late Neogene Chronostratigraphy for the Central Paratethys. Comments and Replies, Neogene Newsletter, 6, 25-59, 1999b.

Salvador, A. (Ed.): International Stratigraphic Guide. International Subcommission on Stratigraphic classification of International Commission on Stratigraphy, The Geological Society of America, $215 \mathrm{pp}, 1994$.

Steininger, F. F., Müller, C., and Rögl, F.: Correlation of Central Paratethys, Eastern Paratethys and Mediterranean stages, in: Royden, L. H. and Horváth, F. (Eds.): The Pannonian Basin: a study in basin evolution, AAPG Mem., 45, 79-87, 1988.

Steininger, F. F., Bernor, R. L., Fahlbusch, V., and Mein, P.: European Neogene marine/continental chronologic relations, in: Lindsay, E. H., Fahlbusch, V., and Mein, P. (Eds.): European Neogene Mammal Chronology, Plenum Press, New York, 1546, 1990.

Stevanović, P. M.: Pontische Stufe im engeren Sinne - Obere Congerienschichten Serbiens und der angrenzenden Gebiete. Serbische Akademie der Wissenschaften, Sonderausgabe, Mathematisch-Naturwissenschaftliche Klasse, 2, Beograd, 187, 1-351, 1951.

Stevanović, P. M., Nevesskaya, L. A., Marinescu, F., Sokać, A., and Jámbor, Á. (Eds.): Chronostratigraphie und Neostratotypen, Neogen der westlichen (“Zentrale") Paratethys 8, Pontien, Jazu and Sanu, Zagreb-Beograd, 952pp, 1990.

Ujszászi, K. and Vakarcs, G.: Sequence stratigraphic analysis in the South Transdanubian region, Hungary, Geophysical Transactions, 38, 2-3, 69-87, 1993.

Vail, P. R.: Seismic stratigraphy interpretation procedure, AAPG Studies in Geology, 27, 1, 1-10, 1987.

Vakarcs, G.: Sequence stratigraphy of the Cenozoic Pannonian basin, Hungary, PhD thesis, Rice University, Houston, Texas, 514 pp, 1997.

Vakarcs, G., Vail, P. R., Tari, G., Pogácsás, Gy., Mattick, R. E., and Szabó, A.: Third-order Miocene-Pliocene depositional sequences in the prograding delta complex of the Pannonian Basin, Tectonophysics, 240, 81-106, 1994.

Vass, D., Kovác, M., and Lexa, J.: Molasse basins and volcanic activity in west Carpathian Neogene. Its evolution and geodynamic character, Geol. Carpathica, 39, 539-561, 1988.

Vass, D., Repcok, I., Balogh, K., and Halmai, J.: Revised radiometric time-scale for central Paratethyan Neogene, Ann. Inst. Geol. Publ. Hung. LXX, 423-434, 1987. 